\title{
Ashleigh Wilson
}

\section{THE TRAIN}

Only five minutes. No, more like three. Have to hurry! Amy doesn't want to miss her train. If she's late home from uni her parents will yell at her. They don't trust her so they're always accusing her of things she didn't do. Amy is certain they hate her; they sure as hell don't understand her.

She frowns and tightens her grip on her boyfriend's hand as she weaves through the crowd of people blocking her way. Why does there have to be so many people? Josh isn't walking fast enough, so she drags him along as she hurries to Flinders Street Station.

Stuck at the edge of the road, Amy taps her feet and stares at the angry red man until he turns green, then the couple hurry across the road along with the countless others swarming to the station. Amy unzips her bag as she's walking, and fumbles around for her wallet. It's frustrating how it always seems to find its way to the bottom of the bag.

Zip. Zop. Thump.

The ticket barriers open and close like mechanical jaws. Amy hurries through; she can't stand the thought of it closing on her.

Amy turns and scans the crowd for Josh. There are too many people, she feels smothered. Finally, his familiar jet black hair and cute round face come into view. She grabs his hand and they hurry down the slope, dodging the slower people, and up another to Platform 3.

'The next train to depart from Platform 3 will be the 6.35 Belgrave, running express from Richmond to Glenferrie, Glenferrie to Camberwell then stopping all stations to Belgrave, via the City Loop. Train now departing.'

They sprint the rest of the way and jump on the train seconds before it leaves. The couple stand in front of the door for a moment catching their breath, and scanning the train for available seats. A double seat at the back of the carriage

Iоo | Offset no. Iо 
looks inviting. Josh leads the way, while Amy holds her bag close to avoid hitting anyone.

Josh stands aside to let Amy sit by the window. Once they're both seated Amy squeezes Josh's hand. He smiles at her, his warm brown eyes lighting up, he squeezes back and kisses her cheek. He's the one person that understands her, and is always there for her. The only person who makes her feel good about herself. She smiles; she's so lucky to have him.

Josh yawns and settles down, resting his head on his girlfriend's shoulder.

'I'm so tired,' he groans.

'You're always tired.' Amy teases rolling her eyes and smiling.

She leans her head lightly against his, and stares blankly out the window. It's difficult to see out because of how dark it is, but she can see a vague silhouette of the buildings moving past.

'Now arriving at Southern Cross,' the automated female voice announces.

As the train pulls into the station, Amy notices the blur of people waiting on the platform. She frowns and looks up at the station's high wavy ceiling, which makes her think of a giant cage. That's how she feels sometimes, caged, like she's not allowed to have a life of her own, like they're always judging her.

Beeeeeeep.

The doors open and people pile in. The new additions find their seats. The train's already packed. A few unfortunate ones are left standing-clinging to the green poles. A tall, skinny man, with a long nose, wearing a suit at least two sizes too small. A young woman, with a tired face and rumpled hair and clothes, hangs wearily to a nearby pole. A short, stocky fellow in a pinstripe suit with oily, slicked-back hair and a frown on his face, leans his back against a rail close to the door. A middle-aged woman wearing too much makeup, which emphasises her wrinkles and the mole on her chin, rather than hide them, clings rigidly to the nearest pole.

By the next stop, those who are standing are either crushed against the sides of the train or moving up the carriage. It's an interesting sight, the business men and women trying to ignore one another's existence. Hiding behind the pages of their $M X$ s, some with glassy eyes and others with headphones clogging their ears.

Amy's gaze drifts to the back of the seat in front of her, at the crudely scratched tags and messages, "SLINKY", and "JS 4 AJ 4 EVA". Amy can't believe it, it's a message Josh wrote years ago when they'd first started going out.

The lights begin to flicker.

Offset no. IO $\mid$ IOI 
Once.

Amy raises her head and glances at the long flat lights on the ceiling. No one else stirs.

Twice.

A few people look up, annoyed that their reading is interrupted.

On. Off. On. Off. On. Off.

It doesn't turn back on this time.

Amy closes her eyes, it's easier to pretend the lights are still on that way. The sounds take over. The drone of the engine, the clicking and squealing of the wheels. She can feel her heart beat, can hear it.

Why is it so quiet?

Why isn't anyone complaining about the lights?

She squeezes Josh's hand. He doesn't respond. His weight on her shoulder has grown heavier. She hears a snort beside her. He's asleep.

Flash. The lights turn back on. Amy opens her eyes slowly squinting against the returned light. She blinks a couple of times, and looks down the carriage ahead of her.

Everyone is gone.

She looks around in disbelief.

Where is everyone?

The carriage is empty. The seats are littered with abandoned newspapers and magazines. The only movement is an empty Coke bottle rolling back and forth across the floor with each sway of the train.

Amy nudges Josh with her shoulder. He groans.

'Wake up,' she urges.

Josh is slow to rise and looks at Amy with his eyes half closed.

'Everyone's gone.'

'Wha ...?'

'Everyone's gone,' Amy repeats herself, her voice rising in pitch.

Josh turns his head scanning the empty carriage.

'Hey, you're right,' he grins and slips his arm around her waist as he leans forward to kiss her. She pushes him away.

'Don't you understand?' Amy cries. 'Everyone is gone.'

'So?'

'Don't you see? They've just disappeared. They were here one minute then the lights started flickering and poof, they're gone, vanished.'

'Now that's just ridiculous,' Josh dismisses her with a wave of his hand, 
'They must have just gotten off somewhere.'

'Josh,'Amy speaks slowly and deliberately, trying to make him to understand, to believe her. 'The train hasn't stopped. We're still in the City Loop. We are not even at Melbourne Central yet. Don't you get it?' Amy grabs his arms roughly, 'They have all disappeared. Where could they have possibly gone?'

Josh frowns.

Amy twists to look through the window behind to see into the next carriage. 'Look, that carriage is empty too.'

Josh turns to look, 'Shit.'

Amy narrows her eyes at him, frowning.

'Sorry,' Josh says sheepishly. 'Well there's got to be some kind of logical explanation. Are you sure you didn't fall asleep?'

'Of course I'm sure!' Amy snaps. 'You're the one who fell asleep!'

'Okay, okay,' Josh says raising his hands in defence.

Amy is on the verge of tears.

'Hey, it's alright,' Josh says gently, and holds out his arms. 'Come 'ere.'

He draws her to him, wrapping his arms tightly around her. Amy buries her face against his chest, trying to hold back the tears that are threatening to start. The warmth of his body is comforting, but it doesn't stop the racing of her heart or the crazy thoughts that keep running through her head. She becomes aware that her whole body is shivering.

Josh clears his throat, 'Uh ... shouldn't we be at Melbourne Central by now?' Amy sits up, stares at his worried face, her eyes drift to the window. She gasps. 'What's wrong?'Josh asks. He turns his head to see what she sees. His jaw drops. The window is like a mirror against the dark, and in it is the reflection of the crowded train. 